\title{
Retrieving Beneficial Outcomes through Increased Level of Awareness about Value Management in Saudi Construction Industry - A Survey-based Approach
}

\author{
Dr. Abdullah Mohammed Alshehri* \\ College of Engineering, Majmaah University, \\ Majmaah 11952, Saudi Arabia \\ Dr. Abdulrahman S. Bageis \\ Taibah University P.O.Box 344, \\ Saudi Arabia
}

\author{
Dr. Ibrahim I. Falqi \\ College of Engineering, King Khalid University, \\ Abha 61411, Saudi Arabia. \\ Dr. Saleh Alsulamy \\ College of Engineering, King Khalid University, \\ Abha 61421, Saudi Arabia
}

\author{
Dr. Tariq A. Alsahli \\ King Abdulaziz university, \\ College of Engineering (Rabigh Branch,) \\ Rabigh, Saudi Arabia
}

\begin{abstract}
To describe a survey regarding the positive and beneficial outcomes of increased awareness about value management within Saudi construction industry. A quantitative research design is used to identify positive and beneficial outcomes of increased awareness about value management. In this regard, a total of $\mathbf{1 3 7}$ employees were enrolled in the study from 500 construction companies of Saudi Arabia. Data was collected through postal questionnaire comprising of three major aspects; awareness, application and applicability of value management in construction industry. Descriptive statistics using SPSS give numerical results of the data collected. The results have shown that $80 \%$ of construction companies seek to achieve value management in construction companies. Furthermore, the results have shown that $70.1 \%$ of employees were aware of the applicability of value management at briefing stage while $67.2 \%$ employees acknowledge that application of value management improves projects outcome in construction companies. These findings indicate a better understanding of construction companies and employees toward the application of value management for achieving projects outcome in construction projects. The study has concluded that there is an increased level of awareness for benefits and consequences of applying value management in construction companies.
\end{abstract}

Keywords-Briefing Stage; Application; Construction; Value Management; Saudi Arabia

\section{INTRODUCTION}

Construction industry plays a major role in Saudi Arabia due to increased production of oil (Alotaibi, Sutrisna \& Chong, 2016). However, Saudi Arabia being a developing country requires sound and effective construction companies for sustaining its economic growth. The construction industry is likely to offer different production ways for majority of the industries. Several research have studied the causes of delays in construction projects in Saudi Arabia during last two decades (Falqi, 2004; Albogamy et al. 2013; Al Mobarak et al. 2013). These research have accounted the perspectives of consultants, contractors, and clients explicitly. Poor experience and qualifications have resultant into ineffective planning and scheduling of the project. Similarly, stakeholders and project delays are resultant through inaccurate estimation of tasks and other aspects of construction project (Albogamy et al. 2013). The main reasons for defects in the public projects include; inadequate regulatory frameworks, poor stakeholder management, and financial constraints (Ikediashi, Ogunlana \& Alotaibi, 2014). On the other hand, value management is responsible for alleviating constraints within the delivery of projects in Saudi Arabia after scrutinizing the functions for clarifying project objectives and improving cost savings (Al-Gahtani et al., 2015). Value management is defined as an organized and structured team approach, which helps in determining the association between different projects and its outcomes (Soliman \& Spooner, 2000). The main aim of value management is to create the best value for project that is based on the achievements of project functions. Value management is likely to provide an analytical and structured process, which helps to increase the value of money and deliver necessary functions (Lin \& Shen, 2007). Usually, these functions depend on the required levels of quality that are attained at the lowest overall cost. It tends to utilize the multidisciplinary value team to maximize the functional value of any project through proper management of its 
developmental stages (Sik-wah Fong et al., 2001). Previously, Alalshikh \& Male (2010) have proposed a value management approach for the design bid-build procurement method in Saudi public sector for realigning the client and contractor value systems throughout the construction stage. Similarly, Al-Yami \& Price (2006) have assessed the feasibility of using value management for accelerating the integration of sustainability based on clients' attitudes and level of existing knowledge. Al-Gahtani, et al. (2015) have identified key performance indicators for value management in Saudi construction industry based on different policies and strategies, market conditions, and competitive environments. Therefore, the study aims to describe a survey regarding the positive and beneficial outcomes of increased awareness about value management within Saudi construction industry. The novelty of this study lies in the measurement of value management's performance that identifies the effectiveness of performance, reliability, and functionality of construction projects. Thereby, this study is significant in assessing the awareness level about value management among constructors, stakeholders, and project managers. The scope of this study is restricted to Saudi Arabia, since there is limited research conducted about the implementation of value management in the construction industry in terms of level of awareness.

\section{A. Research Question}

What are the beneficial outcomes achieved through the increased awareness of value management in Saudi construction industry?

\section{LITERATURE REVIEW}

Value management is a systematic, analytical and structured process, seeking to accomplish value for money by endowing all the relevant functions with the required extent of performance and quality at the lowest total cost. In addition, it is referred as a technique that enhances client value in processes, products, systems, and projects, which have been accepted globally. Phyo \& Cho (2014) have investigated the level of awareness and practice about the existing value management in Myanmar construction industry. A Likert scale has been used to investigate the awareness level and practice of respondents about value management. An average index method has been used for analyzing data. The findings have shown a moderate level of awareness and practice about value management among respondents. In contrast, the level of uncertainty and misunderstanding still exists among respondents. Thereby, the study has shown a concern towards a sluggish and unprofessional attitude of employees in Myanmar construction industry. Lop, et al. (2014) have identified the level of awareness on value management practice amongst construction developers. A total of 81 project managers, general managers, and professionals are recruited from 34 developers company to identify the awareness of value management. The findings obtained from quantitative methods have identified that employees are extensively aware with the value management problems in Malaysia. Thereby, Lop, et al. (2014) have suggested the integration of value management amongst construction developers in Malaysia. Similarly, another study conducted by Fathoni, Zakaria \& Rohayu (2013) determined the acceptance and application of value engineering and life cycle cost analysis in Malaysia construction industry. The study has used a survey questionnaire for determining the awareness and acceptance of sustainable construction among employees. The findings have determined that sustainability and balance in quality are major concerned factors in Malaysian construction industry. Similarly, findings have also indicated that the implementation and awareness of value engineering and life cycle cost analysis is sluggish. In addition, 50\% respondents are moderately aware about the acceptance and implementation of value engineering. AlSanad (2015) has reported opportunities for stimulating sustainable construction practices in Kuwait. A total of 504 local stakeholders, associated with construction industry, were included in this study through snowball sampling technique. The findings have reported that sustainable construction in Kuwait construction industry is sluggish due to lack of awareness amongst local stakeholders. Thereby, the study emphasizes need of increasing awareness of sustainable construction and implementation of policies and incentives for stimulating sustainable construction. Another study conducted by Kim, Lee, \& Nguyen (2016) have identified barriers of increasing awareness and applying value management in Vietnamese construction industry. A questionnaire survey method was used to collect responses from industrial practitioners in the construction projects. The findings have identified that lack of awareness was one of the major hindrance factors in the construction industry of Vietnam. Similarly, factor analysis has identified lack of value management application documents, workshop, and qualified personnel. Thereby, the study imposes the implementation of value management in construction industry of Vietnam.

Tabatabaee, et al. (2018) have investigated the barriers in integrating lean thinking in the construction industry of Malaysia. A questionnaire survey has been used to collect responses from 140 postgraduate students associated with the construction industry. The findings have shown that postgraduate students were aware with the concept of lean thinking. In contrast, findings have shown a moderate awareness in construction management students within the concept of lean thinking. Omar, et al. (2016) have identified the awareness level of green building concepts, environmental factors and outline cost amongst Jordanian construction companies. A survey questionnaire has been used to collect responses from 76 owners, contractors, and consultants of construction companies. The findings have indicated that there is a moderate level of awareness and working experience among owners, contractors and consultants of construction companies. Moreover, findings have indicated that lack of value management expertise and additional incurred costs and time were the major barriers in the implementation of value management.

The empirical evidence has indicated that level of awareness and understanding is an essential aspect in the implementation of value management. Several researches have encouraged to implement value management and to increase level of awareness in construction industries (Phyo \& Cho, 2014; Fathoni, Zakaria \& Rohayu, 2013; Lop et al, 
2014; AlSanad, 2015). However, the level of awareness in the implementation of value management has not been researched extensively in the context of Saudi Arabia as per the knowledge. Thereby, this study postulates that increased level of awareness can allow construction companies to achieve beneficial outcomes:

$H_{1}$ : The increased level of awareness associates with beneficial outcomes in the Saudi construction industry

\section{DATA COLLECTION AND RESEARCH METHODOLOGY}

The study aims to investigate and elaborate the beneficial outcomes of value management within the Saudi construction industry. The research strategy has used quantitative research to review the understanding, beliefs, and awareness of individuals, regarding the practicing of value management. Quantitative research refers to the subjective aspect of the study, which pursues to achieve insights and to comprehend the perceptions of the people. The reason for using this research strategy was its appropriateness in reviewing understandings, views, beliefs and opinions of people. Furthermore, identifying increasing level of awareness about value management is limited in the context of Saudi Arabia.

\section{Data Collection}

A primary quantitative data collection method has been used to gather responses regarding value management and level of awareness in construction industries. The data is collected through postal questionnaire to gather facts, views, and opinions from the respondents. Postal questionnaire is a widely used data collection technique for conducting the survey study.

\section{Sample Size}

The questionnaire is distributed to 500 construction organizations in Saudi Arabia. The fieldwork research was divided into sections including; organizational experience, level of application, and level of awareness. The study mainly gathers information regarding the awareness of value management among from 137 respondents.

\section{Questionnaire Development}

A close-ended questionnaire was developed to fulfill the research aim and to cover level of awareness (Appendix 1).

\section{Analysis Approach}

The obtained data was analyzed using descriptive statistics. Moreover, respondents were asked to answer questions, which require comments.

\section{RESULTS}

The questionnaire is divided into two sections namely organization's background and level of awareness. Table 1 shows the business or services of construction companies, which they are providing to their clients and customers. The findings have shown that $81 \%$ construction companies were providing services as contractors while $16 \%$ construction companies were providing services as consultant companies. In addition, $2.9 \%$ construction companies were providing both and other services to its clients (Figure 1).

Table 1. Organization's Business

\begin{tabular}{ccrrrr}
\hline & Frequency & Percent & $\begin{array}{c}\text { Valid } \\
\text { Percent }\end{array}$ & $\begin{array}{c}\text { Cumulative } \\
\text { Percent }\end{array}$ \\
\hline Valid & Contractor & 111 & 81.0 & 81.0 & 81.0 \\
& Consultant & 22 & 16.1 & 16.1 & 97.1 \\
& Other & 4 & 2.9 & 2.9 & 100.0 \\
& Total & 137 & 100.0 & 100.0 & \\
\hline
\end{tabular}

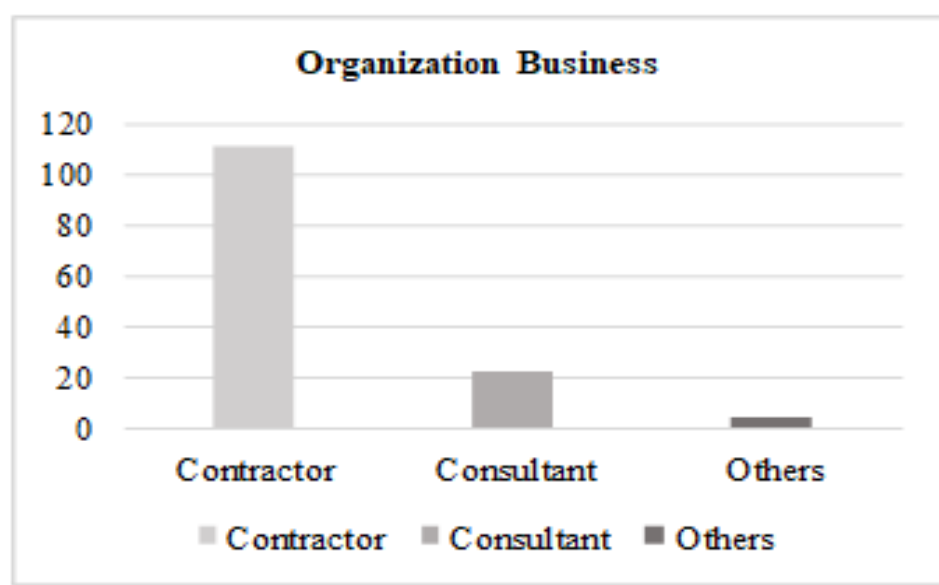

Figure 1. Organization Business

In response to number of employees, there are $46.7 \%$ construction companies consisting of 50-250 employees while $41.6 \%$ construction companies consist of more than 250 employees. From Figure 2, it is illustrated that 12 construction companies consist of 10-49 employees. The respondents were asked about the interest or willingness of construction companies when they seek to achieve value management in construction companies. The results have shown that $80 \%$ construction companies seek to achieve value management in construction companies while $20 \%$ construction companies asserted that value management is not achieved when seeking in construction projects (Table 2). This finding indicates a better understanding of construction companies and employees toward the awareness of value management in construction projects (Figure 3)

Figure 2. Number of Employees

\section{Number ofEmployees}

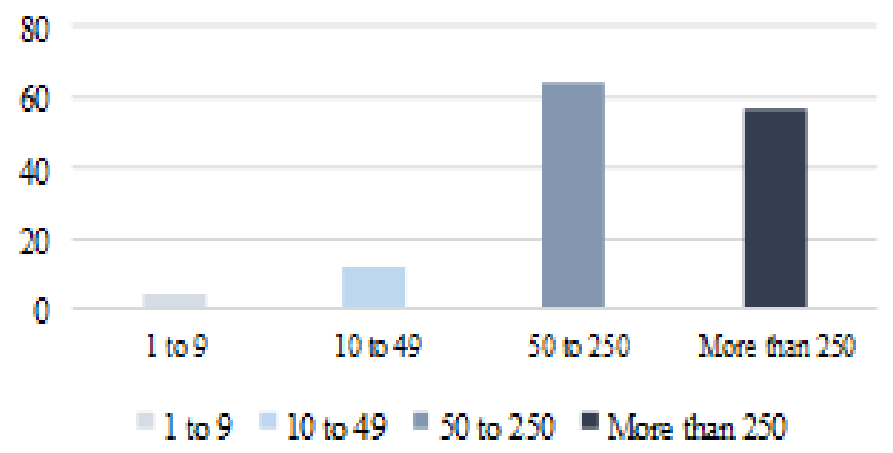


Table 2. Value Management Seeks to Achieve in Construction Projects

\begin{tabular}{cccccc}
\hline & Frequency & Percent & Valid Percent & $\begin{array}{c}\text { Cumulative } \\
\text { Percent }\end{array}$ \\
\hline Valid & Yes & 110 & 80.3 & 80.3 & 80.3 \\
& No & 27 & 19.7 & 19.7 & 100.0 \\
& Total & 137 & 100.0 & 100.0 & \\
\hline
\end{tabular}

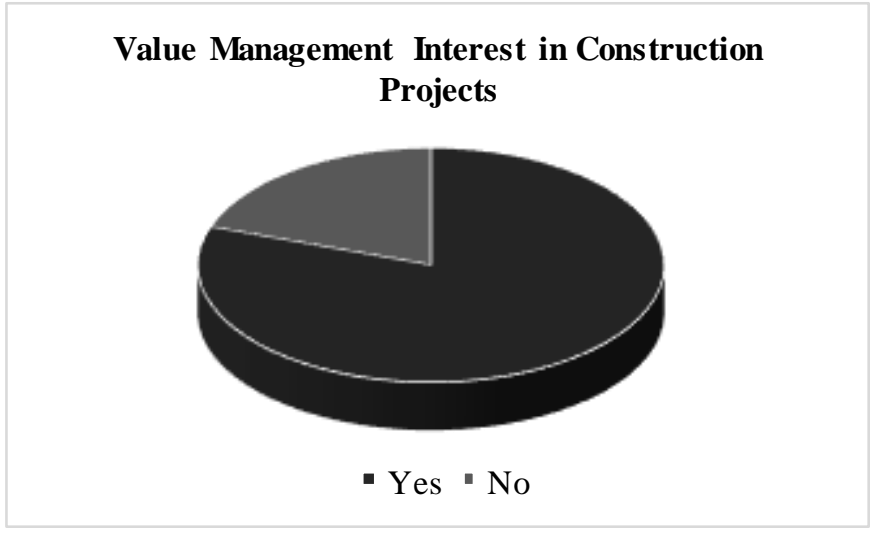

Figure 3.Value Management interest in Construction Projects

Table 3 has revealed the awareness level of employees toward the applicability of value management at briefing stage. The findings have shown that $70.1 \%$ employees were aware of the applicability of value management at briefing stage while $29.9 \%$ employees were aware of the applicability of value management at briefing stage. These results have shown a better understanding of employees and companies toward the applicability of value management at briefing stage (Figure 4).

Table 3. Value Management's Applicability at Briefing Stage

\begin{tabular}{ccrrrr}
\hline & & Frequency & Percent & $\begin{array}{c}\text { Valid } \\
\text { Percent }\end{array}$ & $\begin{array}{c}\text { Cumulative } \\
\text { Percent }\end{array}$ \\
\hline Valid & Yes & 96 & 70.1 & 70.1 & 70.1 \\
& No & 41 & 29.9 & 29.9 & 100.0 \\
& Total & 137 & 100.0 & 100.0 & \\
\hline
\end{tabular}

\section{Value Management Applicability}

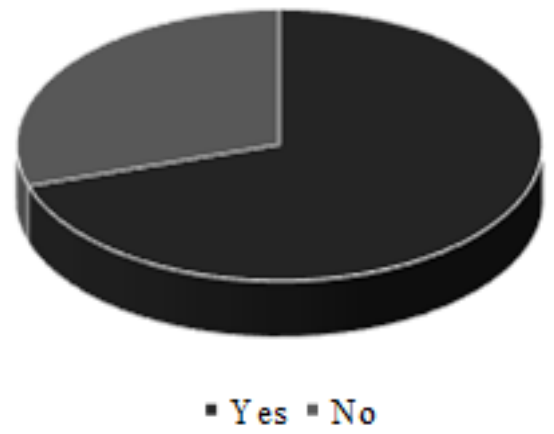

Figure 4. Value Management Applicability

The respondents were asked whether application of value management improves projects outcome or not. The results have shown that $67.2 \%$ employees acknowledge that application of value management improves projects outcome in construction companies while $32.8 \%$ construction companies asserted that the application of value management do not improves projects outcome in construction companies (Table 4). This finding indicates a better understanding of construction companies and employees toward the application of value management for achieving projects outcome in construction projects (Figure 5).

Table 4. Application of Value Management improving Projects Outcome

\begin{tabular}{ccrrrr}
\hline & Frequency & Percent & $\begin{array}{c}\text { Valid } \\
\text { Percent }\end{array}$ & $\begin{array}{c}\text { Cumulative } \\
\text { Percent }\end{array}$ \\
\hline Valid & Yes & 92 & 67.2 & 67.2 & 67.2 \\
& No & 45 & 32.8 & 32.8 & 100.0 \\
& Total & 137 & 100.0 & 100.0 & \\
\hline
\end{tabular}

\section{Application of Value Management}

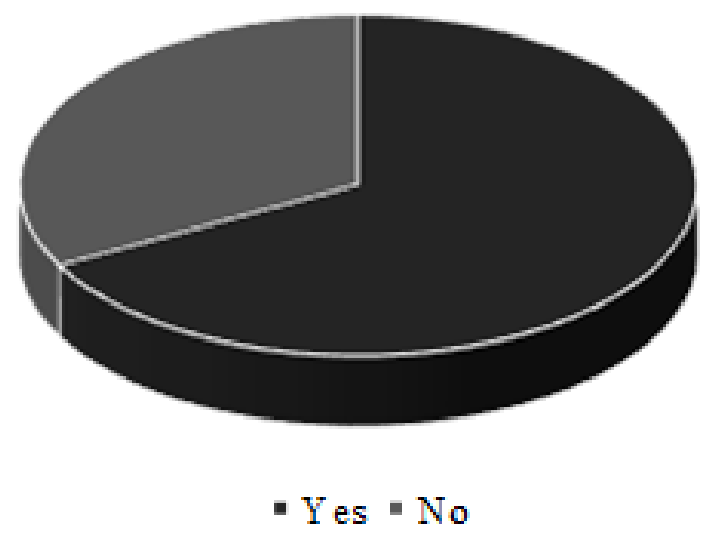

\section{DISCUSSION}

The study has assessed a better understanding of construction employees toward awareness of value management, applicability of value management and application of value management in construction projects. Furthermore, the responses have shown that employees were aware of the value management, its applicability at briefing stage, and its application in enhancing project outcomes. These findings have been in line with the findings of Saleh \& Alalouch (2015) and Gerges et al (2017). Saleh \& Alalouch (2015) have found that awareness of value management is important for construction projects and to enhance the success of construction projects. Moreover, the study has recommended that the changes of industry framework are based on a full awareness of stakeholders toward sustainability achievement in construction. The success of sustainable construction practices is also relied on the public awareness of environmental issues. Similarly, Gerges et al (2017) have asserted that process and technology are important factors for increasing the level of awareness of stakeholders. Moreover, the study has indicated that the application of value management in construction industry is important to overcome the challenges and issues exist in the construction 
industries. In contrast, the study has further revealed that unawareness of the technology and expensive software are major barriers to the application of value management.

In the context of applicability of value management, Al-shabbani (2015) has examined that it is entirely associated with cultural characteristics of the middle east and also influences on the business environment and management style of the companies. Furthermore, the study has recommended that the applicability of value management assists the construction company in tacking the issues such as cost, completion time and inefficient management practices. Similarly, Durdyev et al (2018) have indicated that lack of awareness and knowledge about value management practices in construction companies can cause detrimental results toward the construction projects. Thereby, the study has put forth the implications of value management in developing energy-efficient buildings, healthy indoor environment, reducing material consumption, and durable materials for the extension of buildings. Abuzar et al (2016) have identified that mostly employees $(52 \%)$ were aware of the practices and importance of value management in construction companies. This finding is in-line with the findings of the current study, which shows $80 \%$ awareness of employees toward the adoption and applicability of value management in construction companies. Moreover, the findings have shown that civil engineers were the mostly influenced employees with the success of value management adoption in construction projects. Thereby, these individuals have recommended for the implementation of value management practices in construction projects on a higher extent.

Lop et al (2014) have also shown that stakeholders and employees associated to the construction projects were aware of the positive implications of value management in construction companies. Therefore, the study has recommended that increasing level of awareness can mitigate the impact of existing risks and gaps of construction projects. Lourens (2016) have pinpointed that the adoption of value management in construction projects is significant in increasing the awareness of values and success of construction companies. Thereby, the study has recommended that construction companies should focus on the adoption of value management practices to provide new information to associated stakeholders. Mesbah (2014) has also revealed that the performance of construction companies is entirely associated with the effective value management practices. The aforementioned studies have profoundly revealed that awareness of value management is important in increasing the information of stakeholders and employees. Furthermore, employees' awareness certainly assists in implementing value management extensively.

\section{CONCLUSION}

The study has aimed to assess the benefits of awareness of value management in the Saudi construction industry. The study has found that there is an increased level of awareness of value management in construction companies. Similarly, the study has concluded that there are good understandings of the value management process and its applicability at briefing stage. Lastly, the study has concluded that there is an increased level of awareness for benefits and consequences of applying value management in construction companies. Thereby, the study has recommended that there should a common framework of value management process that can tackle the construction industry of Saudi Arabia by undertaking benefits of other frameworks. Moreover, construction industry should focus on training programs and university studies to increase value management. future studies should adopt quantitative approach to identify the awareness and success of value management in construction industry numerically. Furthermore, they can adopt qualitative approach to foresee the opinions and perceptions of stakeholders to the application of value management.

\section{REFERENCES}

[1] Abuzar, A. S., Ramya, R., Nida, L. M, \& Geetha K. J. (2016). "Awareness and Adoption of BIM in Construction Industry". International Journal on Recent and Innovation Trends in Computing and Communication, 4(4), 204-208.

[2] Alalshikh, M. A., Male, S., \& CSSBB, M. (2010, June). "Proposing a VM approach for the design-bid-build procurement method in the Saudi public sector". In SAVE International Conference, Long Beach, California, USA.

[3] Al-Gahtani, K., Al-Sulaihi, I., Al Rashed, R., \& Batarfi, A. (2015). "Key Performance Indicators for Value Management in Saudi Construction Industry". International Journal of Application or Innovation in Engineering \& Management (IJAIEM), 54-62.

[4] Alotaibi, N. O., Sutrisna, M., \& Chong, H. Y. (2016). "Guidelines of Using Project Management Tools and Techniques to Mitigate Factors Causing Delays in Public Construction Projects in Kingdom of Saudi Arabia". Journal of Engineering, Project, and Production Management, 6(2), 90.

[5] AlSanad, S. (2015). "Awareness, drivers, actions, and barriers of sustainable construction in Kuwait". Procedia engineering, 118 969-983. Doi: https://doi.org/10.1016/j.proeng.2015.08.538

[6] Al-shabbani, Z. (2015). "The Applicability of Western Management in the Middle East".

[7] Al-Yami, A. M., \& Price, A. D. (2006). "Assessing the feasibility of using value management to accelerate the implementation of sustainability".

[8] Bowen, P., Jay, I., Cattell, K., \& Edwards, P. (2010). "Value management awareness and practice by South African architects: an empirical study". Construction Innovation, 10(2), 203-222. Doi https://doi.org/10.1108/14714171011037192

[9] Durdyev, S., Zavadskas, E. K., Thurnell, D., Banaitis, A., \& Ihtiyar A. (2018). "Sustainable Construction Industry in Cambodia: Awareness, Drivers and Barriers. Sustainability", 10(2), 392. Doi: https://doi.org/10.3390/su10020392

[10] Falqi, I. (2004). "Delays in project completion: a comparative study of construction delay factors in Saudi Arabia and the United Kingdom". Unpublished MSc. Thesis, School of the Built Environment, Heriot-Watt University.

[11] Fathoni, U., Zakaria, C. M., \& Rohayu, C. O. (2013). "Value engineering awareness study for sustainable construction in Malaysia". In IOP Conference Series: Earth and Environmental Science (Vol. 16, No. 1, p. 012089). IOP Publishing. Doi https://doi.org/10.1088/1755-1315/16/1/012089

[12] Gerges, M., Austin, S., Mayouf, M., Ahiakwo, O., Jaeger, M., Saad, A., \& Gohary, T. E. (2017). "An investigation into the implementation of Building Information Modeling in the Middle East". Journal of Information Technology in Construction (ITcon), 22(1), 1-15.

[13] Ikediashi, D. I., Ogunlana, S. O., \& Alotaibi, A. (2014). "Analysis of project failure factors for infrastructure projects in Saudi Arabia: A multivariate approach". Journal of Construction in Developing Countries, 19(1), 35.

[14] Kim, S. Y., Lee, Y. S., \& Nguyen, V. T. (2016). "Barriers to Applying Value Management in the Vietnamese Construction 
Industry". Journal of Construction in Developing Countries, 21(2), 55. Doi: https://doi.org/10.21315/jcdc2016.21.2.4

[15] Lin, G., \& Shen, Q. (2007). "Measuring the performance of value management studies in construction: critical review". Journal of Management in Engineering, 23(1), 2-9. Doi: 10.1061/(asce)0742597x(2007)23:1(2)

[16] Lop, N. S., Apandi, M. A. M., Kamar, I. F. M., Salleh, N. M., Mamter, S., \& Hamdan, N. A. M. (2014). "Identifying the Level of Awareness on Value Management Practice amongst Construction Developers". In MATEC Web of Conferences (Vol. 15, p. 01029). EDP Sciences. Doi: https://doi.org/10.1051/matecconf/20141501029

[17] Lourens, W. (2016). Implementation of value management in the South African construction industry ,Doctoral dissertation, University of Johannesburg.

[18] Mesbah, M. (2014). Value Management for Construction Projects Via an Expert System Framework, (Doctoral dissertation, Eastern Mediterranean University (EMU)-Doğu Akdeniz Üniversitesi (DAÜ).

[19] Omar, B., Hiyassat, M., Sweis, G. J., Abdallah, A. B., Saleh, R., \& Sweis, R. J. (2016). "Evaluation of green building awareness in the construction industry: the case of Jordan". Interdisciplinary Environmental Review, 17(3-4), 209-231. Doi: https://doi.org/10.1504/ier.2016.080236

[20] Phyo, W. W. M., \& Cho, A. M. (2014). "Awareness and practice of value engineering in Myanmar construction industry". International Journal of Scientific Engineering and Technology Research, 3(10), 2022-2027.

[21] Saleh, M. S., \& Alalouch, C. (2015). "Towards sustainable construction in Oman: Challenges \& opportunities". Procedia engineering, $118, \quad 177-184 . \quad$ Doi: https://doi.org/10.1016/j.proeng.2015.08.416

[22] Sik-wah Fong, P., Shen, Q., \& Cheng, E. W. (2001). "A framework for benchmarking the value management process. Benchmarking": An International Journal, 8(4), 306-316. Doi: $10.1108 / 14635770110403800$

[23] Soliman, F., \& Spooner, K. (2000). "Strategies for implementing knowledge management: role of human resources management". Journal of knowledge management, 4(4), 337-345. Doi: $10.1108 / 13673270010379894$

[24] Tabatabaee, S., Mahdiyar, A., Yahya, K., Marsono, A. K., \& Sadeghifam, A. N. (2018). "Level of Awareness on Lean Thinking Concept in Construction Among Higher Learning Students in Malaysia". Malaysian Journal of Civil Engineering, 29(1) 